\title{
WOOD PULP FOR POLYMER COMPOSITES PRODUCTION
}

\author{
Érick Afonso Agnes ${ }^{1 *}$, Tânia Vieira de Mello ${ }^{1}$, Everton Hillig², Ricardo Yoshimitsu Miyahara ${ }^{3}$ \\ ${ }^{1 *}$ Universidade Estadual do Centro-Oeste, Programa de Pós-Graduação em Ciências Florestais, Irati, Paraná, Brasil - \\ erickagnes@gmail.com/mello.t@hotmail.com \\ ${ }^{2}$ Universidade Estadual do Centro-Oeste, Departamento de Engenharia Florestal, Irati, Paraná, Brasil - hillig@ hotmail.com \\ ${ }^{3}$ Universidade Estadual do Centro-Oeste, Departamento de Física, Guarapuava, Paraná, Brasil - ricardomiyahara@yahoo.com.br
}

Recebido para publicação: 05/06/2019 - Aceito para publicação: 06/03/2020

\begin{abstract}
Resumo
Polpa de madeira para produção de compósitos poliméricos. Este estudo teve por objetivo avaliar se o uso de polpa obtida por processo químico e/ou termomecânico confere melhores características ao compósito do que a farinha de madeira, tradicionalmente usada nestes materiais. As polpas e a farinha de madeira, de Pinus taeda L., foram usadas como reforços em matriz de polietileno de baixa densidade (LDPE), virgem e reciclado, sendo os compósitos extrusados e os corpos de prova moldados por compressão. Na caracterização do material foi utilizada análise térmica, microscopia eletrônica de varredura e ensaios físico-mecânicos. A incorporação das polpas e da farinha de madeira na matriz melhoraram as propriedades mecânicas dos compósitos e reduziram a velocidade de degradação do material. Todos os tipos de reforço agiram como agentes nucleantes, pois os compósitos apresentaram melhores propriedades mecânicas do que o LDPE puro. Houve influência dos parâmetros estudados na resistência a tração e flexão estática e as interações foram significativas. Em geral, os maiores valores de resistência e rigidez foram obtidos com o uso da polpa de processo termomecânico como reforço e os menores valores com o uso da polpa de processo químico, não branqueada. A análise das micrografias mostrou que o agente de acoplamento foi eficaz para compatibilização do reforço com a matriz nos compósitos. Foi possível produzir materiais compósitos com boas propriedades físico-mecânicas e estabilidade térmica melhorada a partir do modelo experimental.
\end{abstract}

Palavras-chave: LDPE, Polpas de madeira, Farinha de madeira.

\begin{abstract}
The use of cellulosic fibers in composites is advantageous compared to inorganic materials, because they present lower density, abrasiveness and cost, besides the renewable origin. This study aimed to evaluate the influence of wood pulp obtained by the chemical (bleached and unbleached) and mechanical process, and wood-flour of Pinus taeda as reinforcement in low density polyethylene (LDPE) matrix. The composites were extruded and the specimens molded by compression. The samples were characterized by thermal analysis, density, mechanical properties and scanning electron microscopy (SEM). The incorporation of the wood pulps and the wood flour in the matrix improved the composites mechanical properties and reduced the rate of material degradation. All fibers types acted as nucleating agents because the composites had better mechanical properties than pure LDPE. There was influence of the studied parameters on tensile and flexural strength and the interactions were significant. In general, the highest values of strength and stiffness were obtained with the use of thermo-mechanical process pulp as reinforcement and the lowest values with the use of unbleached chemical process pulp. micrographs analysis showed that the coupling agent was effective for compatibilizing the wood fibers with the LDPE in the composites. It was possible to produce composite materials with good physical and mechanical properties and improved thermal stability by experimental model.

Keywords: LDPE, Wood pulps, Wood-flour.
\end{abstract}

\section{INTRODUCTION}

The most widely used biomaterial for the production of composites with thermoplastics is wood flour. Besides this, a promising alternative for the manufacture of composites is the wood pulp because differ from wood flour in that fibers are longer than wide, rather than particle like (MATUANA and STARK, 2015). In order to have a reinforcing effect fibers need to have a minimum ratio of length to diameter (aspect ratio). Reinforcement of WPC and improved strength properties may be achieved by using wood fibres with a high aspect ratio and other chemical characteristics (SCHIRP; STENDER, 2010).

To produce and separate the wood fibers, there are different pulping processes, the most common being the chemical, mechanical and thermomechanical. In chemical pulping the cellulose fibers are chemically separated and most of the lignin is removed in the pulping process where the wood chips, chemicals and steam react in a digester. This process is also known as the Kraft process, where fiber separation occurs by dissolving lignin. (BLEDZKI; GASSAN, 1999). To finalize the process, the pulp can be bleached to obtain a whiter product with

FLORESTA, Curitiba, PR, v. 51, n. 1, p. 044-053, jan/mar 2021.

Agnes, E. A. et.al.

ISSN eletrônico 1982-4688 
lower amounts of impurities and greater resistance to aging, yellowing and mechanical strength. These effects are mainly linked to lignin in chemical pulp (EK et al., 2009).

In mechanical pulping and with thermal or chemical additives, the wood chips are physically defibrated by friction; in the thermomechanical pulping, the refiner is kept at a temperature close to $120^{\circ} \mathrm{C}$. Thermomechanical pulping is the process of producing pulp in a pre-steamed wood chip refiner. The wood chips are treated with saturated steam at a temperature of about $125^{\circ} \mathrm{C}$. The temperature above $130{ }^{\circ} \mathrm{C}$ should be avoided for both hardwood and coniferous, since the lignin glass transition point would be exceeded. Fiber separation occurs mainly in the middle lamella where the highest concentration of lignin is found (ZHAO; LIU, 2013).

Chemical pulping results in the wood pulp most commonly used in papermaking. The fibrous elements submitted to the pulping are networks of polymers that have varied sizes, the larger ones being cellulose and the smaller ones being lignin. Lignin when treated with alkaline solutions (acid hydrolysis) shows a rupture of the ether bonds between the phenyl propane units, which causes the formation of phenolic groups responsible for their solubilization. The cellulose presents a degree of polymerization that varies between 1000 and 15000 and were scattered in hemicellulose and amorphous lignin which have degree of polymerization in the range of 50 to 200. The degree of polymerization defines the solubility in alkaline or aqueous medium. The lower the degree of polymerization of a substance, the greater its solubility, thus, in the case of lignin, loss of the mechanical qualities of resistance can occur, mainly by decomposition, when used as reinforcement in composite (CARVALHO et al, 2009).

The mechanical properties of polymer composites depend on 4 factors: the properties of the matrix; the properties of reinforcement; the compatibility between reinforcement and matrix; and the dispersion of the reinforcement in the matrix (MIAO; HAMAD, 2013).

Beltrami et al., (2014), stated that the alkaline treatment that occurs in chemical pulping promotes changes in the structure of wood fibers due to the removal of hemicellulose and lignin. According to the authors the alkaline treatment promotes an improvement in the adhesion of fibers in the matrix, which improves the mechanical properties of composites.

The bond between the matrix and reinforcement phases of a composite is related in the superficial characteristics among them, which should allow efficient transfer of tension between the components. Problems adhesion between the fiber and the polymer matrix can reduce the transfer of efforts by compromising the mechanical properties of the composite (SREEKUMAR, P. A. et al., 2009). Thus, the surface alkaline treatment that occurs in the fibers during chemical pulping tends to promote greater adhesion between the phases.

Due to its high degree of polymerization, higher crystallinity and because it has larger molecules than the other non-cellulosic components that make up the fibers, cellulose tends to be more resistant to mechanical, chemical or thermal degradation so its durability and resistance as an individual fiber is perceptibly higher than the aggregated compounds with smaller molecule. (CARVALHO et al, 2009).

The physical properties of plastics reinforced with vegetable fibers are generally affected by the properties of their components, wood and thermoplastics, and their fiber and matrix relationship. The fiber component influences the composite properties not only by the type of wood used, but also by the geometry, its aspect ratio, reinforcement manufacturing process and its composition (BLEDZKI; GASSAN, 1999).

Both the wood flour and the mechanical pulp are basically composed of cellulose, hemicellulose and lignin, and the pulp obtained by chemical process contains only cellulose, and the other components have already been dissolved by chemical processes. Carvalho et al. (2009) studied the composition of the wood and concluded that due to cellulose present molecule size, crystallinity and degree of polymerization higher than the other constituents, therefore, pulp presents better mechanical, physical and thermal characteristics than wood flour.

Therefore, thermomechanical, and chemical, pulp features characteristics that make it a promising candidate for the utilization in polymer composites. Since pulp production causes physical and chemical changes in the wood used, and these changes may be beneficial for obtaining composites with improved characteristics (MERTENS et al., 2017), this work aimed to verify that the use of pulp obtained by different processes and for different commercial currently uses provide composites with improved properties. In this study, low density polyethylene (LDPE), virgin and recycled matrix, were used for production of composites with three types of fibers: bleached chemical pulp, unbleached chemical pulp and mechanical pulp, for comparation with composites produced with wood flour of Pinus taeda.

\section{MATERIALS AND METHODS}

\section{Raw material}

To prepare the composites was used wood flour, bleached and unbleached pulp chemistry pulp and mechanical pulp obtained from Pinus taeda wood, from industries of the region of Irati-PR. 
In the composites matrix phase, virgin low density polyethylene (vLDPE) and recycled (rLDPE) were used, the virgin polymer coming from Braskem S.A. (Table 1) and the recycled polymer obtained in a plastic packaging industry that uses this material.

All reinforcing materials were kiln dried under the same condition at $70^{\circ} \mathrm{C}$ for 48 hours as they came from the same forest species. After drying, the pulps were milled in an adapted laboratory grinder. With this, a material with more homogeneous particles was obtained.

A commercially available coupling agent Polybond 3009 with Maleic Anhydride Content of 0.8 at $1.2 \%$ was used to improve the interaction between the fiber and matrix phase in the $10 \%$ proportion (Table 1).

Tabela 1. Propriedades do LDPE e Polybond.

Table 1. Properties of LDPE and Polybond.

\begin{tabular}{lccc}
\hline Property & Standard & LDPE & Polybond \\
\hline Density $\left(\mathrm{g} / \mathrm{cm}^{3}\right)$ & ASTM D 1505 & 0.918 & 0.950 \\
Fluidity index $190^{\circ} \mathrm{C} / 2,16 \mathrm{~kg}$ & ASTM D 1238 & 8.3 & 5.0 \\
VICAT softening temperature $\left({ }^{\circ} \mathrm{C}\right)$ & ASTM D 1525 & 86 & --- \\
Melting Point $\left({ }^{\circ} \mathrm{C}\right)$ & ---- & --- & 127 \\
Yield strength $(\mathrm{Mpa})$ & ASTM D 638 & 9 & --- \\
Modulus of elasticity - Bending $(\mathrm{Mpa})$ & ASTM D 790 & 200 & --- \\
\hline
\end{tabular}

Source: BRASKEM, 2015; ADDIVANT, 2013.

\section{Thermal analysis}

For all materials were made thermal characterization processes. Simultaneous thermal analysis (STA) was performed, which was applied in a single equipment at the same time and for the same sample, thermogravimetric analysis (TGA) and differential scanning calorimetry (DSC). Thus, the same test conditions are assumed for the two analyzes.

Samples with $6 \mathrm{mg}$ mass were submitted to the test in a TA equipment, model SDT Q600 under a nitrogen atmosphere at a flow of $50 \mathrm{ml} . \mathrm{min}-1$ starting at room temperature $\left(20^{\circ} \mathrm{C}\right)$ at a constant speed of $25^{\circ} \mathrm{C} / \mathrm{min}$ to reach $900{ }^{\circ} \mathrm{C}$ remaining in isotherm for 10 minutes and then cooled at a rate of $10{ }^{\circ} \mathrm{C} / \mathrm{min}$ until reaching $20^{\circ} \mathrm{C}$.

\section{Experimental design}

In order to evaluate the properties of the composites produced with wood fibers obtained by different processes and to compare them with the composites produced with wood flour, samples were produced by varying the type of fiber (pulp and flour of wood) and the type of polymer (virgin or recycled). The experimental model is presented in Table 2.

Tabela 2. Modelo experimental.

Table 2. Experimental design.

\begin{tabular}{ccc}
\hline Composite Type & Fibers Type (35\%) & Matrix Type (65\%) \\
\hline 1 & BP & vLDPE \\
2 & UP & \\
3 & MP & \\
4 & WF & rLDPE \\
5 & BP & \\
7 & MP & WF \\
8 & WP flour; vLDPE = Virgin LDPE; rLDPE = Recycled LDPE.
\end{tabular}

\section{Composites production and molding}

The composites were made in a single-screw extruder with a thread diameter of 50 millimeters with four heating zones. A quantity of 1100 grams of material was pre-determined for each composite, and then $350 \mathrm{~g}$ fibers (32\%), 650 g matrix (59\%) was added and 100g additive (15\% on the matrix weight) was added as coupling of matrix/fibers.

The extruded material, after cooling, was crushed using an external grinder to easily compression molding process to be then oven dried at $100^{\circ} \mathrm{C}$ for 24 hours. After drying, the composite was ground again in a Willey mill, brand TECNAL, model T6 - 650 .

The preparation of the test specimens was carried out by the compression process in a laboratory hydraulic press with $600 \times 600 \mathrm{~mm}$ plates, electric heating and a capacity of 90 tons. A steel mold of the specimens was used, taking into account the dimensions suggested in the ISO-527/12 standards for tensile strength and ISO 178/11 
for static bending. The ground composites were distributed in the mold and then pressed at $11,77 \mathrm{Mpa}$ and $180{ }^{\circ} \mathrm{C}$ for 12 minutes.

\section{Characterization of composites}

Thermal analysis

The same thermal analyzes performed for the starting materials were performed for the composites (see thermal analysis of materials).

\section{Scanning electron microscopy}

The microanalysis was performed with a SEM scanning electron microscope model Vega 3 manufactured by TESCAN, with image magnification of 1000 and 3000 times. During the process, a beam of electrons with power of $10 \mathrm{KW}$ is activated, before atmosphere induced by the vacuum of nitrogen. The distance between the sample and the beam was set at $15 \mathrm{~mm}$. To improve the flow of the electrons in the sample, two plasma electrodes were used to return a thin layer of gold (10 nanometers) in the material.

Physical-mechanical tests and statistical analysis

To determine the density, the same specimens used in the static bending test were used. The volume (S) of the sample was determined by the product of its three dimensions and the density obtained by the mass-volume quotient.

The mechanical tests were performed on an EMIC brand test machine, 30 tons. The specimens were submitted to the tests based on the ISO - 178/11 standards for static bending and ISO - 527/12 for tensile strength.

In the tensile test, seven specimens were used. The tests were carried out using a load cell of $30 \mathrm{KN}$ and with a speed of $5 \mathrm{~mm} / \mathrm{min}$ until its rupture, being determined the following mechanical properties: tensile strength and tensile modulus

The static bending test was performed at a speed of $5 \mathrm{~mm} / \mathrm{min}$ using a $30 \mathrm{kN}$ load cell. Seven specimens of each composite were also tested and elastic modulus and tension in the maximum force (bending strength) were determined.

The results were submitted to the Normality Test and Bartlett's variance homogeneity test. The properties results were submitted to factorial variance analysis, to analyze the main effects and the interaction between the factors. The analysis between factors was complemented by the Tukey test. Then it was done variance analysis between composite type, for analysis of the significant interaction between factors and for comparison with references. All tests were performed at the 5\% error probability level.

\section{RESULTS}

\section{Scanning electron microscopy}

The micrographs of the composites, with ranging from 1000 to 3000 magnifications, allowed to visualize the characteristics that determine how was the adhesion of the fiber and matrix phases in each type of produced composite (Figure 1)
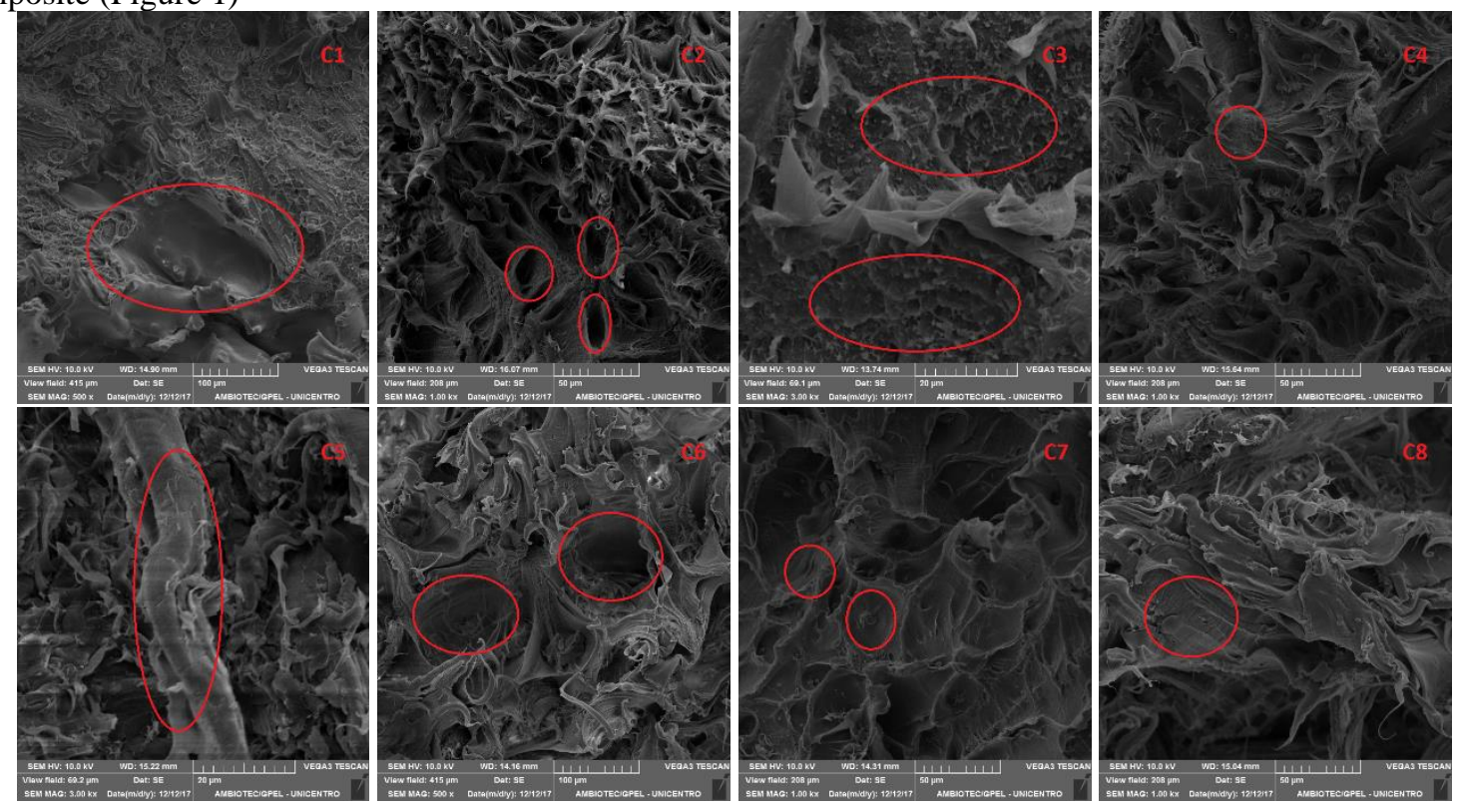

FLORESTA, Curitiba, PR, v. 51, n. 1, p. 044-053, jan/mar 2021.

Agnes, E. A. et.al.

ISSN eletrônico 1982-4688

DOI: $10.5380 /$ rf.v51 i1. 67291 
Figura 1. Microscopia eletrônica de varredura dos compósitos.

Figure 1. Scanning electron micrograph of composites.

\section{Thermal analysis of matrices and wood fibers}

Figure 2 and 3 shows the thermal properties of the raw materials and matrices obtained by DSC and TGA-DTG analysis.

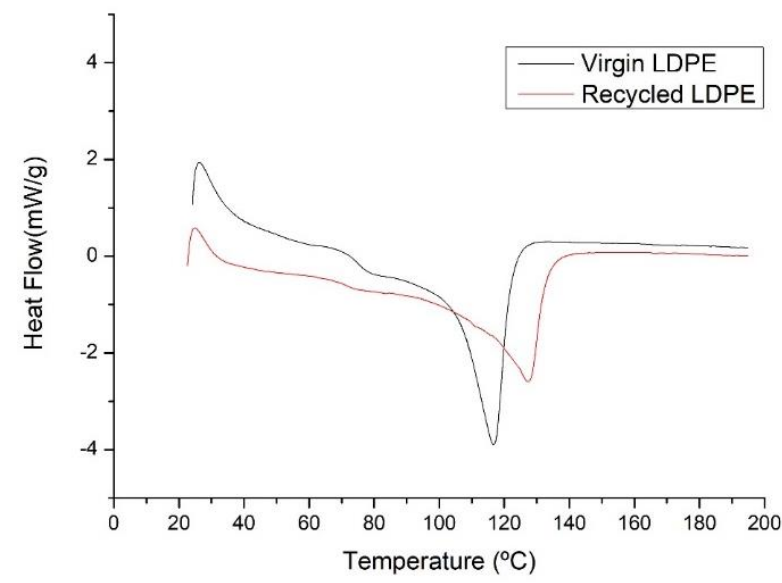

Figura 2. Análise DSC das matrizes.

Figure 2. DSC analysis of the matrices.
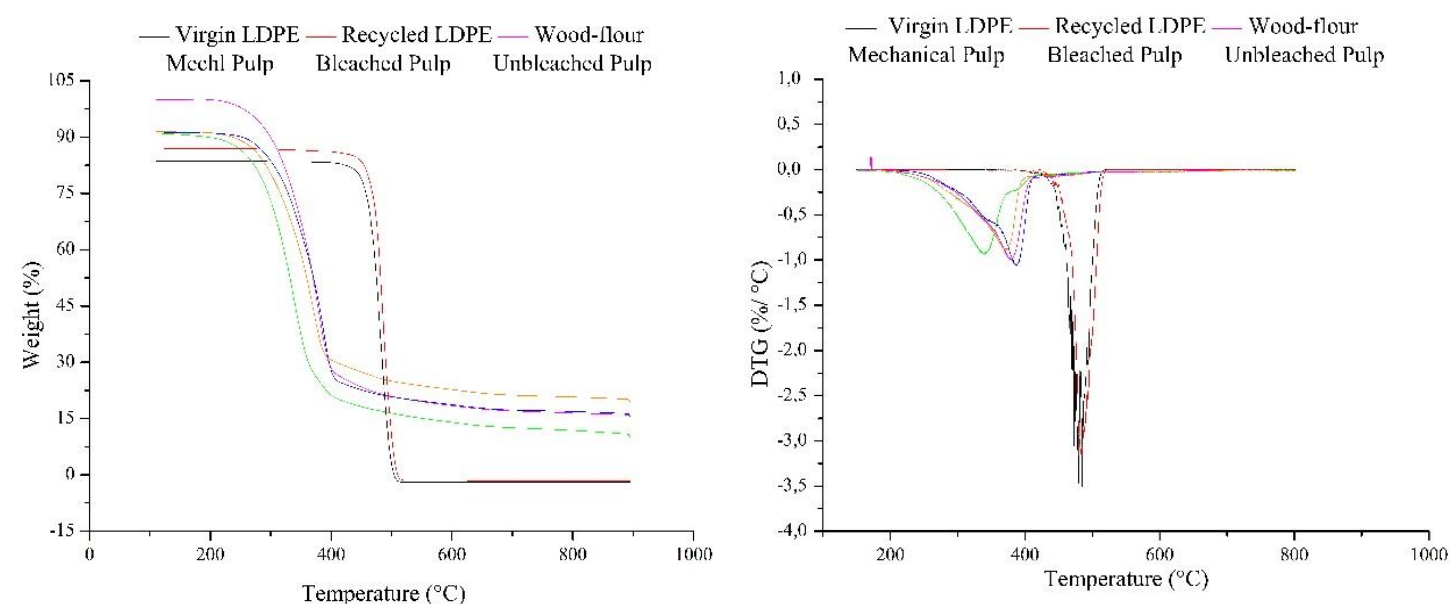

Figura 3. Análises TGA-DTG das matérias primas.

Figure 3. TGA-DTG analysis of raw materials.

Through the DSC, the melting temperature and degree of crystallinity were verified for the pure polymers. It is observed that the melting point of vLDPE is lower than rLDPE, the first at $116.87{ }^{\circ} \mathrm{C}$ and the second at $127.46{ }^{\circ} \mathrm{C}$. As for crystallinity, vLDPE had a higher index (34.12\%) compared to rLDPE (30.94\%).

\section{Thermal analysis of composites}

It can be seen from the TGA curves that all the composites had their mass reduced as a function of temperature increase and subsequent cooling and that all presented total degradation only after the cooling period (Figure 3). At around $500^{\circ} \mathrm{C}$, the mass loss approached the entire material, at which point the curve shows a much slower range of degradation.

The thermogravimetric analysis showed a degradation in two stages for the composites and showed greater stability for the composites than for the isolated raw materials. 

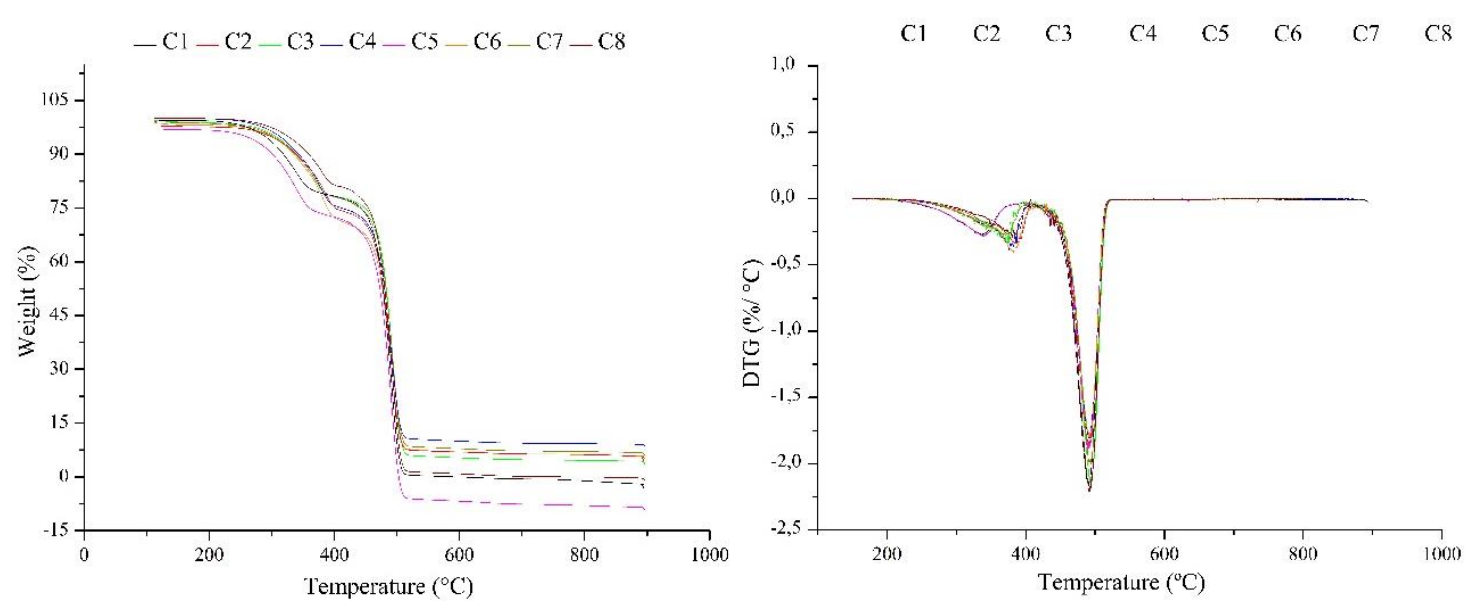

Figura 4. Análises TGA-DTG dos compósitos.

Figure 4. TGA-DTG analyzes of composites.

\section{Physico-mechanical properties of composites}

Table 3 presents the physico-mechanical properties of the composites separated by evaluated factor, as well as the analysis of variance for interaction between the factors.

Tabela 3. Valores médios das propriedades dos compósitos produzidos apresentadas pelo fator estudado. Table 3. Mean values of composite properties produced presented by factor studied.

\begin{tabular}{cccccc}
\hline Factor & Type & St (Mpa) & Et (Mpa) & MOR (Mpa) & MOE (Mpa) \\
\hline \multirow{2}{*}{ Matrix } & vLDPE & $12.7 \mathrm{a}$ & $1229 \mathrm{a}$ & $21.7 \mathrm{a}$ & $809 \mathrm{a}$ \\
& rLDPE & $9.2 \mathrm{~b}$ & $927 \mathrm{~b}$ & $17.3 \mathrm{~b}$ & $633 \mathrm{~b}$ \\
\hline \multirow{5}{*}{ Fiber/flour } & BP & $12.4 \mathrm{~b}$ & $938 \mathrm{~b}$ & $17.9 \mathrm{~b}$ & $637 \mathrm{~b}$ \\
& UP & $7.4 \mathrm{~d}$ & $731 \mathrm{~b}$ & $17.5 \mathrm{~b}$ & $586 \mathrm{~b}$ \\
& MP & $14.4 \mathrm{a}$ & $1798 \mathrm{a}$ & $24.1 \mathrm{a}$ & $1038 \mathrm{a}$ \\
& WF & $9.6 \mathrm{c}$ & $845 \mathrm{~b}$ & $16.5 \mathrm{~b}$ & $621 \mathrm{~b}$ \\
\hline Interaction & F1 x F2 & $11.128^{*}$ & $16.33^{*}$ & $10.30^{*}$ & $45.55^{*}$
\end{tabular}

$\mathrm{St}=$ tensile strength; $\mathrm{Et}=$ tensile modulus; $\mathrm{MOR}=$ static bending strength; $\mathrm{MOE}=$ static bending modulus; Means followed by the same letters do not differ statistically by Tukey test at $5 \%$ error probability. $*$ Significant at $5 \%$ probability of error.

Table 4 shows the physical-mechanical properties of each type of composite, to analyze the interaction between the factors and for comparison with other references.

Tabela 4. Propriedades físico-mecânicas dos compósitos produzidos com diferentes misturas compostas Table 4. Physico-mechanical properties of specimens produced with different composites mixtures.

\begin{tabular}{|c|c|c|c|c|c|c|c|}
\hline Composite & Fiber/flour & Matrix & $\rho\left(\mathrm{g} / \mathrm{cm}^{3}\right)$ & $\begin{array}{c}\mathrm{St} \\
(\mathrm{Mpa})\end{array}$ & $\begin{array}{c}\text { Et } \\
(\mathrm{Mpa})\end{array}$ & $\begin{array}{l}\text { MOR } \\
\text { (Mpa) }\end{array}$ & $\begin{array}{l}\mathrm{MOE} \\
(\mathrm{Mpa})\end{array}$ \\
\hline 1 & BP & \multirow{4}{*}{ vLDPE } & $0.924 \mathrm{a}$ & $12.2 \mathrm{bc}$ & $808 \mathrm{~b}$ & $18.8 \mathrm{~b}$ & $638 \mathrm{~b}$ \\
\hline 2 & UP & & $0.965 \mathrm{a}$ & $9.5 \mathrm{~cd}$ & $707 \mathrm{~b}$ & $18.4 \mathrm{~b}$ & $585 \mathrm{~b}$ \\
\hline 3 & MP & & $0.902 \mathrm{a}$ & $17.9 \mathrm{a}$ & $2540 \mathrm{a}$ & $29.4 \mathrm{a}$ & $1441 \mathrm{a}$ \\
\hline 4 & WF & & $0.925 \mathrm{a}$ & $11.2 \mathrm{bc}$ & $861 \mathrm{~b}$ & $16.5 \mathrm{~b}$ & $571 \mathrm{~b}$ \\
\hline 5 & $\mathrm{BP}$ & \multirow{4}{*}{ rLDPE } & $0.985 \mathrm{a}$ & $12.5 \mathrm{~b}$ & $1069 \mathrm{~b}$ & $17.2 \mathrm{~b}$ & $635 \mathrm{~b}$ \\
\hline 6 & UP & & $0.924 \mathrm{a}$ & $5.4 \mathrm{e}$ & $754 \mathrm{~b}$ & $16.6 \mathrm{~b}$ & $590 \mathrm{~b}$ \\
\hline 7 & MP & & $0.984 \mathrm{a}$ & $10.8 \mathrm{bcd}$ & $1057 \mathrm{~b}$ & $18.9 \mathrm{~b}$ & $634 \mathrm{~b}$ \\
\hline 8 & WF & & $0.892 \mathrm{a}$ & 8.0de & 829 b & $16.5 \mathrm{~b}$ & $671 \mathrm{~b}$ \\
\hline
\end{tabular}

$\rho=$ density of tensile specimens; $\mathrm{St}=$ tensile strength; $\mathrm{Et}=$ tensile modulus; $\mathrm{MOR}=$ static bending strength; MOE = static bending modulus; Means followed by the same letters do not differ statistically by Tukey test at $5 \%$ error probability. Means followed by the same letters do not differ statistically by Tukey test at $5 \%$ error probability.

For the matrix factor, in the static bending, strength (MOR) and the modulus of elasticity (MOE), the virgin LDPE matrix is superior to the recycled matrix. On the other hand, for the tensile, strength (St) and modulus of elasticity (Et), the inverse occurred.

For the factor Fiber/flour, the best results found for St and Et were with the mechanical pulp. Unbleached chemical pulp presented lower results than the other raw materials used. For Et, except for the mechanical pulp, the other fibers type did not present statistical difference. No fibers type was statistically equivalent in the results to tensile strength.

FLORESTA, Curitiba, PR, v. 51, n. 1, p. 044-053, jan/mar 2021.

Agnes, E. A. et.al.

ISSN eletrônico 1982-4688

DOI: $10.5380 /$ rf.v51 i1. 67291 
Among the fibers type studied, the mechanical pulp tends to present higher values than the others. Comparing bleached and unbleached chemical pulp, it can be observed that these presented no statistical difference in their properties. The wood flour and the bleached chemical pulp showed the lowest MOR and MOE values, respectively. Except for mechanical pulp, the other isolated fibers showed no statistical difference.

The effect of interaction between the factors was significant for all levels, indicating that each formulation presented a different behavior of the factor isolated.

\section{DISCUSSION}

\section{Scanning electron microscopy}

According to Figure 4, the presence of air bubbles is observed in the composites of BP + vLDPE (C1), but the composition in general presented good adhesion, exposing a homogeneous rupture surface in the areas that did not occur air bubbles. The presence of bubbles was also verified in the composite of UP + vLDPE (C2), but of greater frequency and smaller size. Both had no aggregates of fibers.

As studied by Carvalho et al. (2009), both wood flour and mechanical pulp are basically composed of cellulose, hemicellulose and lignin, and the pulp obtained by chemical process contains only cellulose, and the other components have already been dissolved by chemical processes.

The alkaline treatment that occurs in chemical pulping promotes changes in the structure of wood fibers due to the removal of hemicellulose and lignin. There is also increased adhesion of fibers in the matrix, which improves the mechanical properties of composites (BELTRAMI et al., 2014). The fibers obtained by the bleaching process go through the same refining steps as the unbleached fibers. However, as the latter was not subjected to the acid bleaching attack, they have less aggregation with the matrix.

The MP + vLDPE (C3) composite has a tangled aspect, joining fibers and matrix, and the effect is seen when the image is enlarged by 3000 times, where a characteristic aspect of matrix dispersion without formation of aggregates is observed.

For WF + vLDPE (C4), the wood flour visibly showed good adhesion to the virgin LDPE matrix. In the micrographs it is observed that the wood flour is enveloped by LDPE structures which form a kind of capsule. Apparently there was no surface breaking in the structures of the particles, which indicates that the matrix fulfilled its purpose of protecting the fibers.

In the micrographs of composites produced with recycled LDPE (C5, C6, C7, C8), it was verified that difference of the pulp phase for LDPE was more evident in relation to composites produced with virgin LDPE, being possible to observed aggregates in greatest magnification. In the mixture occurred aggregates, however, it is observed that there was no breakage of the bond between fibers and matrix. Compared to the virgin LDPE composite, a lower proportion of matrix is observed when recycled LDPE is used, possibly due to the smaller connections forming fewer arrangements. The deficiency of the matrix phase impairs the elastic characteristics of the material consequently favoring the breaking of the fibers.

It is possible to observe the formation of fiber bundles and broken fibers in BP + rLDPE (C5). The rLDPE did not completely involve the fibers, which is the possible reason for its sensitivity. In the UP + rLDPE (C6) composite, a smoother surface is seen, which surrounds the fiber phase and the matrix phase that appears in the form of plates. In this one also the presence of superficial cavities was verified, being able to represent a weak adhesion.

The MP + rLDPE (C7) and the WF + rLDPE (C8) presented characteristics like that of composites C3 and $\mathrm{C} 4$, respectively, since it also showed a tendency to the formation of plates, however with wrinkled surface and the formation of some fibers aggregates.

Hillig et al. (2017), studied composites with different particle sizes of Pinus sp. as reinforcement. The lower the particle size, the higher the melt index of the HDPE, LDPE and PP composites. This reasoning may explain the homogeneity of the mixtures presented here with LDPE, since the higher the fluidity, the less the formation of aggregates.

\section{Thermal analysis of matrices and wood fibers}

Figure 2 shows a difference between the melting points of the recycled and virgin polymers, in a study by Pistor, V. et al. (2010), reprocessed LDPE samples show an increase in the number of branches in some regions of the thermoplastic. According to Coutinho (2003), F. M. B. et al., less branched polymers have a higher melting point. Thus, the recycling process affected the complexity of the chain and consequently in its melting point. It can be seen from the TGA and DTG curves that the virgin LDPE presented thermal variation like the recycled LDPE (Figure 3). The temperature of degradation of the two types of LDPE was of $500^{\circ} \mathrm{C}$. The degree of crystallinity found was lower for rLDPE, however, both polymers showed crystallinity within the range mentioned in the literature from 30 to 54\% (PEACOCK, 2000).

FLORESTA, Curitiba, PR, v. 51, n. 1, p. 044-053, jan/mar 2021. 


\section{Thermal analysis of composites}

According to Figure 3, in general, the thermal behavior of the composites was similar, presenting curves with peaks in near temperature ranges when compared to one composite to another. By the DTG curves, in all the composites, it is possible to observe two main peaks, being the first and less prominent representing the degradation of the fibers where it can be observed by the variation of the curve that the reaction occurred slowly, which for all the composites did not exceed the speed of $0.5 \% /{ }^{\circ} \mathrm{C}$ of mass loss.

Cellulose initiates mass loss at temperatures higher than other wood constituents, having the largest amount of volatiles of all components. However, lignin and hemicellulose decompose at lower rates and with greater mass loss in carbonization. In wood carbonization, it is known that hemicellulose is the first compound to be degraded and lignin the second. Lignin is thermally stronger than wood's carbohydrate components. At temperatures up to $600{ }^{\circ} \mathrm{C}$, hemicellulose mass loss is about $95 \%$; for cellulose, this percentage is around $80 \%$, while in lignin does not exceed 60\% (CORRADINI et al., 2009).

Since the second curve represents the degradation of the LDPE matrix, such a reaction occurs faster than the degradation of the fibers, being between 1.5 and $2 \%$ mass loss per ${ }^{\circ} \mathrm{C}$.

In relation to the degradation of the fibers, when compared with the curves representing the different composites types, there is a tendency to occur in the same way both dispersed in the composite as in its neat state. However, when analyzed in its neat state, total degradation does not occur in the same temperature range as the composite, with a final mass residue of about $15 \%$. The materials have different reactions to heat, and the wood has a lower heat transfer coefficient than LDPE.

In the DTG curve of the unbleached chemical pulp, a small initial peak caused by the variation of the initial velocity in the anticipated degradation of the lignin residues present in the pulp can be evidenced, since this degradation is first by the action of the heat, already for pulp bleached chemistry this curve variation did not occur, there was no interference of the lignin in the material, since it was degraded in the bleaching process.

The thermal behavior of the vLDPE and rLDPE matrices showed an almost imperceptible difference, both matrices being suitable for use in composite exposed to the heat. The DTG curves showed that the rate of degradation of the matrices was like that of the fibers. However, at $500{ }^{\circ} \mathrm{C}$ the material presented all its degraded mass.

Due to the fact that the analyzes were performed with the dried samples, both for the composites and for the raw materials, it was observed the absence of a first depression of the curve, which would represent the loss of water below $100{ }^{\circ} \mathrm{C}$.

\section{Physico-mechanical properties of composites}

According to Table 4, for density, there was no statistical difference between the average values of the composites, due to the use of the same molding method and the same production parameters, although a mean value variation of 0.892 to $0.984 \mathrm{~g} / \mathrm{cm}^{3}$ could be verified. The results verified for the density of each type of composite demonstrate that there was good control of the process, since the general average was of $0.938 \mathrm{~g} / \mathrm{cm}^{3}$, above the density of pure LDPE, combined with the results of scanning electron microscopy analysis, it can be verified that there were few bubbles and faults in the specimens produced.

Regarding the results of St, except the composite produced with bleached chemical pulp, all the others presented difference regarding the use of virgin and recycled matrix, being higher the virgin LDPE. When compared to the results of the pure LDPE produced by Ndlovu et al. (2013), of $11.5 \mathrm{Mpa}$ on average, only the composites produced with mechanical pulp and virgin LDPE (C3) and with bleached pulp (C1 and C5) presented higher average value.

According to Beltrami et al. (2014) the alkaline process that occurs in the bleaching step of the mechanical fibers, explaining the superiority in the results for the $\mathrm{C} 1$ and $\mathrm{C} 2$ tests.

Composites with bleached chemical pulp showed higher mechanical properties than composites that used unbleached chemical pulp. According to COMELATO, J.S. et al (2013), the bleaching step tends to generate fines. Tensile strength of pulps is affected by fines content, higher tensile strengths were observed in pulps with higher fines content. This explains the superiority in the St test verified for composites 1 and 5 compared to 2 and 6 respectively.

The Et results found for all composites produced ranged from 707 to $2540 \mathrm{Mpa}$, higher than the pure LDPE specimens produced by Hillig et al. (2017), of $232 \mathrm{Mpa}$, demonstrating an increase in stiffness with the use of any type of wood fiber in the composite.

Sdrobiş et al. (2012), studied bleached and unbleached pulps of Pinus sp. in the manufacture of LDPE composites, finding Et values of $246 \mathrm{Mpa}$ and $242 \mathrm{Mpa}$, respectively, lower than this study. For St, the authors obtained 10.9 and 10.6 Mpa for bleached and unbleached pulp, respectively, values close to those found in this study. Yang et al. (2016) obtained results for St ranging from 12.20 to 14.13 Mpa, using LDPE matrix and plant peels as reinforcement.

FLORESTA, Curitiba, PR, v. 51, n. 1, p. 044-053, jan/mar 2021. 
Ashori and Nourbakhsh (2010) in a study on particle sizes, compared the species of Quercus castaneifolia C.A. Mey. and Pinus sp. using polypropylene (PP) as a matrix. The results showed that the fiber of Pinus sp. had superior effect in the mechanical properties, which was attributed to the longer length of its fiber. Spence et al. (2010), in their studies on the pulps composition of bleached and unbleached, of hardwood and coniferous wood, concluded that the higher the lignin content the larger the pulp fibril diameter. These studies suggest that a higher content of lignin in the fiber tends to improve the properties of the composites produced with thermoplastics.

For MOR and MOE the results were similar and also followed the same trend as those obtained for Et. Ashori and Nourbakhsh et al. (2010) verify that several characteristics had a differed fiber type of the other like the extractives, granulometry, species, etc., and who had marked effects on the mechanical and physical properties of the composites.

Hillig et al. (2017) for injected LDPE specimens found values of 10.0 Mpa and $206 \mathrm{Mpa}$ for MOR and MOE, respectively, and values of 20.3 Mpa (MOR) and of $542 \mathrm{Mpa}$ (MOE) for composites with sawdust of Pinus taeda. Yang et al. (2016) studying LDPE composites reinforced with vegetal peels obtained results for MOR varying between 10.5 and $19.8 \mathrm{Mpa}$ when improved with one type of dye, values on average lower than those found in the composites studied here.

\section{CONCLUSIONS}

- Composite materials can be produced with good physico-mechanical properties and improved thermal stability. There was improvement in the thermal behavior of the composite with pure LDPE.

- The addition of reinforcement to the matrix reduced the rate of degradation of the material. In the analysis by scanning electron microscopy it was observed that there was good adhesion between the fiber and matrix phases of the composites, evidencing the importance of the use of coupling agent.

- The composites reinforced with mechanical pulp presented the best mechanical properties. The type of pulp affected the mechanical properties. The delignification process was ineffective for quality improvement, however, bleaching improves the quality of the composite produced with chemical pulp.

\section{REFERENCES}

ADDIVANT CORPORATION (2013). Tecnical information Polybond® 3009. https://www.brenntag.com/media/documents/bsi/product_data_sheets/material_science/addivant/polybond_3009 _pds.pdf. Accessed 5 october 2018.

ASHORI, A.; NOURBAKHSH, A. Reinforced polypropylene composites: effects of chemical compositions and particle size. Bioresource technology, v. 101, n. 7, p. 2515-2519, 2010.

BELTRAMI, LÍLIAN VANESSA ROSSA; CRISTINE SCIENZA, LISETE; ZATTERA, ADEMIR JOSÉ. Effect of alkaline treatment of curing fibers on the properties of compounds of a biodegradable matrix. Polímeros, v. 24, n. 3, p. 388-394, 2014.

BLEDZKI, A. K.; GASSAN, J. Composites reinforced with cellulose based fibers. Progress in polymer science, V. 24, n. 2, p. 221-274, 1999.

BRASKEM (2015). Datasheet Revision 7 (Apr/15). Low Density Polyethylene EB853 / 72. Available at: http://www.braskem.com.br/cms/Principal/produto/download?id=buVajtV4yMI=\&folhadados=true. Acessed on: 29 Jul. 2018.

CARVAlHO, W., CANIlHA, L., FERRAZ, A., \& MILAGRES, A. M. F. Uma visão sobre a estrutura, composição e biodegradação da madeira. Química Nova, v. 32, n. 8, p. 1-5, 2009.

COMELATO, J. S., VENTORIM, G., CARASCHI, J. C., \& DOS SANTOS, I. R. Fines generation in eucalyptus kraft pulp bleaching and its effect on paper properties. Revista Árvore, v. 37, n. 1, p. 181-189, 2013.

CORRADINI, E., TEIXEIRA, E. M., PALADIN, P. D., AGNELli, J. A., SILVA, O. R. R. F., \& MATTOSO, L. H. C. Thermal stability and degradation kinetic study of white and colored cotton fibers by thermogravimetric analysis. Journal of Thermal Analysis and Calorimetry, v. 97, n. 2, p. 415, 2009.

COUTINHO, FERNANDA MB; MELLO, IVANA L.; LUIZ, C. Polyethylene: main types, properties and applications. Polímeros: ciência e tecnologia, v. 13, n. 1, p. 1-13, 2003.

EK, MONICA; GELLERSTEDT, GÖRAN; HENRIKSSON, GUNNAR (ED.). Pulping chemistry and technology. Walter de Gruyter, 2009.

FLORESTA, Curitiba, PR, v. 51, n. 1, p. 044-053, jan/mar 2021. 
HILlig, É., BOBADILLA, I., ZATTERA, A. J., LIMA, É. A. A. D., \& MARCHESAN, R. Influence of coconut shell addition on physico-mechanical properties of wood plastic composites. Revista Árvore, v. 41, n. 4, 2017.

MATUANA, L. M.; STARK, N. M. In Faruk and Sain Biofibe Reinforcements in Composites Materials; Elsevier, 2015; pp 648-688.

MERTENS, O.; GURR, J.; KRAUSE, A. The utilization of thermomechanical pulp fibers in WPC: A review. J. Appl. Polym. Sci. 2017, DOI: 10.1002/APP.45161.

MIAO, CHUANWEI; HAMAD, WADOOD Y. Cellulose reinforced polymer composites and nanocomposites: a critical review. Cellulose, v. 20, n. 5, p. 2221-2262, 2013.

NDLOVU, S. S.; VAN REENEN, A. J.; LUYT, A. S. LDPE-wood composites utilizing degraded LDPE as compatibilizer. Composites Part A: Applied Science and Manufacturing, v. 51, p. 80-88, 2013.

PEACOCK, A.. Handbook of polyethylene: structures: properties, and applications. CRC press, 2000.

PISTOR, V.; CHIESA, A.; ZATTERA, A. J. Study of reprocessing of recycled low density polyethylene (LDPE) from tubular film extrusion processing. Polímeros, v. 20, n. 4, p. 269-274, 2010.

SDROBIŞ, A., DARIE, R. N., TOTOLIN, M., CAZACU, G., \& VASILE, C. Low density polyethylene composites containing cellulose pulp fibers. Composites Part B: Engineering, v. 43, n. 4, p. 1873-1880, 2012.

SCHIRP, A.; STENDER, Properties of extruded wood-plastic composites based on refiner wood fibres (TMP fibres) and hemp fibres. European Journal of Wood and Wood Products. v. 68, n. 2, p. 219-231, 2010.

SPENCE, K. L., VENDITTI, R. A., ROJAS, O. J., HABIBI, Y., \& PAWLAK, J. J. The effect of chemical composition on microfibrillar cellulose films from wood pulps: water interactions and physical properties for packaging applications. Cellulose, v. 17, n. 4, p. 835-848, 2010.

SREEKUMAR, P. A., THOMAS, S. P., MARC SAITER, J., JOSEPH, K., UNNIKRISHNAN, G., \& THOMAS, S. Effect of fiber surface modification on the mechanical and water absorption characteristics of sisal/polyester composites fabricated by resin transfer molding. Composites Part A: Applied Science and Manufacturing, v. 40, n. 11, p. 1777-1784, 2009.

YANG, W., GE, L., LV, H., XIA, M., JI, X., \& YAO, Z. Mechanical and thermal properties of low density polyethylene composites filled with dye loaded shell powder. Journal of Applied Polymer Science, v. 133, n. 42, 2016.

ZHAO, XUEBING; LIU, DEHUA. Kinetic modeling and mechanisms of acid-catalyzed delignification of sugarcane bagasse by aqueous acetic acid. BioEnergy research, v. 6, n. 2, p. 436-447, 2013. 